\title{
PENENTUAN RUTE DISTRIBUSI PALLET MESH MENGGUNAKAN METODE SAVING MATRIX (STUDI KASUS : PT. MMM)
}

\author{
Determination Of Pallet Mesh Distribusion Route Using The Saving Matrix Method (Study \\ Case : PT. MMM)
}

\section{Fery Darus Nasution ${ }^{\left.{ }^{*}\right)}$, Ade Momon S ${ }^{2)}$, Risma Fitriani ${ }^{3)}$}

1,2,3) Program Studi Teknik Industri, Fakultas Teknik, Universitas Singaperbangsa Karawang, Jl. H. S. Ronggowaluyo, Telukjambe Timur, Karawang 41361, Indonesia.

\section{Article Information}

Article history:

Received: August, 31, 20

Revised: November, 18, 20

Accepted: January, 13, 21

\section{Keywords:}

Distribution

Saving matrix

Nearest neighbor

Kata kunci:

Distribusi

Saving matrix

Nearest neighbor

\section{A B S T R A C T}

Distribution of products from the company's warehouse PT. MMM to consumers so far the company only uses estimates of consumers which will be passed in one shipment only by looking at the number of requests without considering the shipping routes and distance from the warehouse to the location of the consumer. This study aims to determine an effective shipping route using the saving matrix and nearest neighbor methods then find out distance savings and transportation cost savings. Comparison of the product distribution routes of PT. MMM after using the saving matrix method and the nearest neighbor method results in an effective and efficient route where the initial distribution route is 40 routes into 7 routes for 7 days of product distribution to consumers. The saving matrix method is applied. shows a reduction in the distance of the original shipment of $1,673.6 \mathrm{Km}$ to $810.7 \mathrm{Km}$, thus obtained a savings of a distance of $862.9 \mathrm{Km}$. As well as a significant reduction in transportation costs where the initial cost of transportation of Rp. $4,478,448$.- dropped to Rp. 3,675,951.-, so the company can save on transportation costs by Rp. $802,497 .-$.

\section{A B S T R AK}

Rute pendistribusian produk dari gudang perusahaan PT. MMM ke para konsumen selama ini perusahaan hanya menggunakan perkiraan konsumen mana yang akan dilalui dalam satu kali pengiriman, yaitu hanya dengan melihat jumlah permintaan tanpa mempertimbangkan rute pengiriman dan jarak tempuh dari gudang ke lokasi konsumen. Penelitian ini bertujuan untuk menentukan rute pengiriman yang efektif menggunakan metode saving matrix dan nearest neighbor, kemudian mengetahui penghematan jarak serta penghematan biaya transportasi. Perbandingan rute distribusi produk PT. MMM dengan menggunakan metode saving matrix dan metode nearest neighbor menghasilkan rute yang efektif dan efisien dimana rute awal distribusi sebanyak 40 rute menjadi 7 rute untuk 7 hari pendistribusian produk ke konsumen. Dengan diterapkannya metode saving matrix menunjukan penurunan jarak tempuh pengiriman yang semula $1.673,6 \mathrm{Km}$ menjadi $810,7 \mathrm{Km}$, dengan demikian didapatkan penghematan jarak sebesar $862,9 \mathrm{Km}$. Serta menurunkan biaya transportasi yang signifikan dimana biaya awal transportasi sebesar Rp. 4.478.448.- turun menjadi Rp. 3.675.951.-, sehingga perusahaan dapat menghemat biaya transportasi sebesar Rp. 802.497.

\footnotetext{
${ }^{\star}$ Corresponding Author

Fery Darus Nasution

E-mail: ferynasution55@gmail.com
}

This is an open access article under the $\mathrm{CC}-\mathrm{BY}$ license

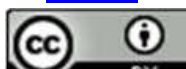




\section{PENDAHULUAN}

Pendistribusian yang baik merupakan salah satu faktor kunci dalam perusahaan agar suatu produk dapat dikirim sampai kepada semua konsumen tepat waktu dan barang dalam kondisi baik. Letak konsumen yang menyebar menyebabkan tiap perusahaan harus benarbenar memikirkan pemilihan mode transportasi yang digunakan baik dari segi kapasitas dan jalur yang akan dilalui [1].

PT. MMM adalah salah satu perusahaan yang bergerak pada bidang industri pembuatan sparepart kendaraan dan fabrikasi. Produk yang dihasilkan oleh perusahaan ini bermacammacam jenis dan model untuk setiap produk disesuaikan dengan permintaan konsumen. Salah satu produk yang sering diproduksi adalah Pallet Mesh, pallet mesh adalah sebuah wadah atau keranjang besi lipat yang terbuat dari bahan besi galvanis model mesh. Pallet Mesh sendiri terdiri dari beberapa ukuran disesuaikan dengan pemakaian dan permintaan, banyak digunakan sebagai wadah material maupun bahan baku, jika tidak digunakan dapat dilipat kembali dan disimpan selama jangka waktu tertentu.

Permasalahan yang sedang dihadapi oleh PT. MMM yaitu pada proses distribusi perusahaan yang menggunakan pengiriman langsung dari perusahaan ke konsumen tanpa melalui gudang atau jasa pengiriman, belum adanya perencanaan distribusi produk yang baik, hal ini disebabkan oleh jumlah rute yang terlalu banyak, jarak pengiriman terlalu jauh, terbatasnya alat angkut dan tingginya biaya transportasi yang dikeluarkan perusahaan dengan jumlah rute distribusi sebanyak 40 rute yang memiliki jarak $1.673,6 \mathrm{Km}$ dan biaya transportasi sebesar Rp. 4.478.448.-. Selama ini perusahaan sedang mencari solusi untuk mengembangkan sistem pendistribusian yang efektif dan efisien dalam melakukan proses pengiriman barang dengan mempertimbangkan jarak antar konsumen dan kapasitas kendaraan perusahaan yang digunakan sehingga tidak berdampak pada banyaknya rute yang dilalui dan jauhnya jarak tempuh kendaraan dalam melakukan pengiriman sehingga dapat meminimalkan biaya transportasi. Dalam pengiriman barang juga sering terjadi tidak konsistennya jadwal di setiap pengirimannya dikarenakan belum adanya standar rute distribusi yang jelas dan tidak konsistennya jadwal pendistribusian perusahaan untuk setiap harinya. Salah satu metode yang digunakan untuk memecahkan permasalahan rute pengiriman, yaitu metode saving matrix dan metode nearest neighbor.
Permasalahan rute distribusi dapat dianalisis dengan menggunakan pendekatan manajemen transportasi dan distribusi. Metode saving matrix merupakan suatu metode yang digunakan untuk menyelesaikan masalah didalam transportasi lalu menentukan rute distribusi agar dapat meminimalkan jarak atau dengan kata lain penggabungan konsumen kedalam satu rute, selain itu penerapan metode saving matrix juga bertujuan untuk meminimalkan jarak tempuh perjalanan serta biaya transportasi dengan mempertimbangkan kapasitas kendaraan yang digunakan [2]. Dalam menentukan rute distribusi produk dengan menggunakan metode saving matrix diperlukan beberapa entitas yang digunakan seperti jarak konsumen, rute awal distribusi, lokasi konsumen, kapasitas kendaraan, biaya distribusi dan permintaan. Sehingga, langkah-langkah yang harus ditempuh dengan mengidentifikasikan matrix jarak, mengidentifikasikan matrix penghematan atau saving matrix, mengalokasikan kendaraan atau rute, hingga mengurutkan konsumen kedalam rute yang sudah ditentukan. Dalam metode saving matrix dan nearest neighbor juga dapat menghasilkan rute distribusi usulan yang lebih sedikit dari rute distribusi yang semula diterapkan perusahaan, sehingga menghasilkan usulan rute distribusi untuk meminimalkan biaya transportasi [3]. Pada penelitian M. Rahmi, penerapan metode saving matrix dan diperoleh efisiensi jarak dan biaya yang optimal [4], lalu pada penelitian Ade Momon dan Damara perusahaan dapat megurangi jarak sebesar $22 \%$ atau $1,690.9 \mathrm{~km}$ dan dapat menghemat biaya transportasi hingga mencapai $38 \%$ atau sebesar Rp. 28,494,021.-/bulan.[5]

Penelitian ini dilakukan untuk memperkuat penelitian diatas dan tambahan beberapa penelitian yang telah dilakukan sebelumnya yang terdapat pada daftar pustaka, dalam penelitian ini dilakukan analisa mengenai penentuan rute distribusi produk Pallet Mesh di PT. MMM menggunakan metode saving matrix dan nearest neighbor dengan mempertimbangkan jarak konsumen dan rute pengiriman yang dilalui, sehingga dapat mengurangi total jarak tempuh dan biaya transportasi serta memperoleh rute distribusi yang efektif dan biaya transportasi yang efisien bagi perusahaan.

\section{METODE PENELITIAN}

Penelitian ini dilakukan di PT. MMM dengan melakukan pengamatan secara langsung di lapangan, studi literatur juga dilakukan untuk memperoleh hasil penelitian yang sesuai dengan 
permasalahan yang dibahas dengan cara membaca, memahami dan mempelajari teoriteori yang berhubungan dengan topik kajian metode penyelesaian untuk memecahkan permasalahan yang dihadapi dalam penelitian ini. digunakan metode saving matrix dan metode nearest neighbor, kemudian total biaya transportasi. Beberapa data yang diperlukan dalam penelitian ini yaitu kapasitas alat angkut, peta perjalanan, data permintaan, matrix jarak, biaya kendaraan dan gaji driver. Alur pengolahan data yang dilakukan dalam penelitian ini dapat dilihat pada Gambar 1.

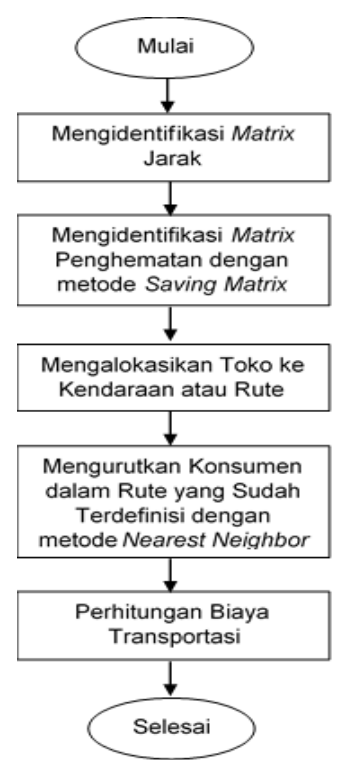

Gambar 1. Diagram Alir Pengolahan Data

\subsection{Metode Saving matrix}

Metode saving matrix digunakan untuk menentukan rute distribusi dan meminimalkan jarak tempuh dengan mempertimbangkan beberapa kendala yang ada, diperlukan jarak sebagai fungsi tujuan apabila telah diketahui jarak lokasi pengiriman konsumen. Beberapa langkah yang harus dikerjakan dalam metode ini yaitu :

a. Mengidentifikasi matrix jarak, pada langkah ini diperlukan jarak antara perusahaan ke masing-masing konsumen dan jarak antar konsumen.

b. Menentukan matrix penghematan, dengan menghubungkan konsumen 1 dan konsumen 2 kedalam satu rute, maka jarak yang dikunjungi adalah dari perusahaan ke konsumen 1 kemudian ke konsumen 2 dan dari konsumen 2 kembali lagi ke perusahaan.

c. Mengalokasikan tujuan dalam kendaraan dan rute, Pertama kali yang dilakukan pada langkah ini adalah mengalokasikan konsumen ke rute yang berbeda, setelah itu menggabungkan konsumen satu dengan konsumen lainnya dan mengalokasikan jenis kapasitas kendaraan yang sesuai kebijakan yang sudah ditetapkan sebelumnya kedalam satu rute dengan nilai penghematan terbesar,

d. Mengurutkan tujuan dalam rute yang terdefinisi, mengurutkan konsumen kedalam rute yang sudah terdefinisi dengan prinsip meminimalkan jarak tempuh kendaraan [6].

\subsection{Metode Nearest neighbor}

Metode ini diawali dengan pengiriman dari gudang, kemudian dilanjutkan dengan mencari lokasi konsumen yang belum dikunjungi dengan jarak terpendek dari gudang, kemudian langkahlangkah perhitungannya juga dilakukan pencarian konsumen dengan jarak terdekat dari konsumen yang telah dikunjung. Hal ini terus dilakukan sampai pada konsumen yang terakhir [7].

\section{HASIL DAN PEMBAHASAN}

Dari pengumpulan data yang sudah didapat PT. MMM mempunyai 11 konsumen yang tersebar di beberapa kawasan industri yang berada di kota Karawang, Bekasi dan Jakarta. Untuk mempermudah perhitungan maka untuk setiap konsumen diberikan kode. Untuk data tujuan konsumen terdapat pada Tabel 1.

Tabel 1. Kode Konsumen

\begin{tabular}{lc}
\hline \multicolumn{1}{c}{ KONSUMEN } & KODE \\
\hline PT. Yamaha Motor Parts Indonesia & $\mathrm{A}$ \\
PT. Jtekt Indonesia & $\mathrm{B}$ \\
PT. Parker Metal Treatment & $\mathrm{C}$ \\
Indonesia & \\
PT. Fujita Indonesia & $\mathrm{D}$ \\
PT. SKF Indonesia & $\mathrm{E}$ \\
PT. Toyobesq Precision Part & $\mathrm{F}$ \\
Indonesia & \\
PT. Nestle Indonesia & $\mathrm{G}$ \\
PT. Tiger Sash Indonesia & $\mathrm{H}$ \\
PT. Kubota Machinery Indonesia & $\mathrm{I}$ \\
PT. Menara Terus Makmur & $\mathrm{J}$ \\
PT. Astra Nippon Gasket Indonesia & $\mathrm{K}$ \\
\hline
\end{tabular}




\subsection{Kapasitas Alat Angkut}

PT. MMM dalam menyalurkan produknya ke semua konsumen dengan menggunakan kendaraan milik perusahaan yaitu kendaraan jenis Hino Dutro 300 dengan kapasitas alat angkut 60 pcs pallet mesh yang dapat di tampung dalam sekali pengiriman.

\subsection{Data Permintaan}

Data tersebut merupakan produk yang dipesan oleh konsumen untuk dikirimkan oleh supplier sesuai dengan kebutuhan yang diharapkan, pada Tabel 2. dijelaskan data permintaan dan waktu distribusi masing-masing konsumen PT. MMM bulan Februari - Maret berdasarkan informasi yang di berikan perusahaan.
Tabel 2. Permintaan Konsumen

\begin{tabular}{lr}
\hline \multicolumn{1}{c}{ KONSUMEN } & ORDER \\
\hline PT. Yamaha Motor Parts Indonesia & 100 pallet \\
PT. Jtekt Indonesia & 50 pallet \\
PT. Parker Metal Treatment Indonesia & 60 pallet \\
PT. Fujita Indonesia & 40 pallet \\
PT. SKF Indonesia & 30 pallet \\
PT. Toyobesq Precision Part Indonesia & 25 pallet \\
PT. Nestle Indonesia & 40 pallet \\
PT. Tiger Sash Indonesia & 10 pallet \\
PT. Kubota Machinery Indonesia & 10 pallet \\
PT. Menara Terus Makmur & 5 pallet \\
PT. Astra Nippon Gasket Indonesia & 50 pallet \\
\hline
\end{tabular}

Tabel 3. Data Matrix Asal Tujuan (Km)

\begin{tabular}{|c|c|c|c|c|c|c|c|c|c|c|c|c|c|}
\hline No & $\begin{array}{l}\text { Ke } \\
\text { Dari }\end{array}$ & G & A & B & $\mathrm{C}$ & D & E & $\mathrm{F}$ & G & $\mathrm{H}$ & I & $\mathrm{J}$ & K \\
\hline 1 & G & - & & & & & & & & & & & \\
\hline 2 & A & 14 & - & & & & & & & & & & \\
\hline 3 & B & 17 & 18 & - & & & & & & & & & \\
\hline 4 & $\mathrm{C}$ & 25 & 29 & 38 & - & & & & & & & & \\
\hline 5 & D & 15 & 0,75 & 13 & 35 & - & & & & & & & \\
\hline 6 & E & 50 & 54 & 63 & 32,4 & 55 & - & & & & & & \\
\hline 7 & $\mathrm{~F}$ & 14 & 1,5 & 13 & 37 & 2,3 & 62 & - & & & & & \\
\hline 8 & G & 18 & 18,6 & 2 & 39 & 20 & 65 & 18,6 & - & & & & \\
\hline 9 & $\mathrm{H}$ & 27,8 & 31 & 39,8 & 9,62 & 31,8 & 27 & 31 & 41 & - & & & \\
\hline 10 & I & 56 & 59 & 68 & 38 & 60 & 14 & 60 & 70 & 34 & - & & \\
\hline 11 & $\mathrm{~J}$ & 21 & 24 & 33 & 10,2 & 25 & 35,6 & 24 & 34,4 & 11 & 40 & - & \\
\hline 12 & K & 15 & 0,5 & 13 & 35,8 & 0,25 & 61 & 2,04 & 14,4 & 37 & 66 & 31,6 & - \\
\hline
\end{tabular}

\subsection{Data Jarak Konsumen}

Pada langkah ini diperlukan jarak antara PT. MMM ke masing-masing konsumen Pada Tabel 3. dijelaskan data jarak yang digunakan dalam penelitian ini berdasarkan pencarian pada aplikasi Google Maps, Jalan yang digunakan adalah jalan raya yang terdapat dalam aplikasi selama lima kali pengukuran pada waktu kerja sehingga didapatkan rata-rata keakuratan jaraknya. Saving matrix adalah metode untuk meminimalkan jarak, rute dan ongkos dengan mempertimbangkan kapasitas kendaraan.[8]
Metode saving matrix digunakan untuk menentukan rute dan meminimumkan jarak dengan mempertimbangkan beberapa kendala yang ada, diperlukan juga jarak sebagai fungsi tujuan apabila diketahui koordinat atau jarak rill tujuan pengiriman semua jarak tempuh kendaraan.[9] Langkah-langkah yang harus dikerjakan, yaitu mengidentifikasi matrix jarak, menentukan matrix penghematan, mengalokasikan tujuan dalam kendaraan dan rute, mengurutkan tujuan dalam rute yang terdefinisi [10]. 
Rumus:

$\begin{aligned} S(A, C) & =J(G, A)+J(G, C)-J(A, C) \\ & =14+25-29=10 \mathrm{Km}\end{aligned}$

Dimana $S(A, C)$ adalah penghematan jarak (saving) yang diperoleh dengan menggabungkan rute konsumen $\mathrm{A}$ dan $\mathrm{C}$,untuk keseluruhan di tunjukan Tabel 4.
Berdasarkan hasil perhitungan jarak penghematan pada Tabel 4. konsumen bisa digabungkan sampai batas kapasitas kendaraan yang ada, penggabungan akan dimulai dari nilai penghematan terbesar dengan memaksimalkan penghematan.

Tabel 4. Matrix Penghematan Jarak (Km)

\begin{tabular}{|c|c|c|c|c|c|c|}
\hline \multicolumn{7}{|c|}{ Pengiriman Tanggal 24 Februari 2020} \\
\hline Konsumen & A & C & D & $\mathbf{F}$ & K & \\
\hline A & 0 & & & & & \\
\hline C & 10 & 0 & & & & \\
\hline D & 28,25 & 5 & 0 & & & \\
\hline $\mathbf{F}$ & 26,5 & 2 & 26,7 & 0 & & \\
\hline $\mathbf{K}$ & 28,5 & 4,2 & 29,75 & 27,96 & 0 & \\
\hline Demand & 20 pcs & 10 pcs & 10 pcs & 10 pcs & 10 pcs & \\
\hline \multicolumn{7}{|c|}{ Pengiriman Tanggal 25 Februari 2020} \\
\hline Konsumen & $\mathbf{A}$ & B & C & $\mathrm{E}$ & $\mathbf{G}$ & $\mathbf{I}$ \\
\hline A & 0 & & & & & \\
\hline B & 13 & 0 & & & & \\
\hline C & 10 & 4 & 0 & & & \\
\hline $\mathbf{E}$ & 10 & 4 & 42,6 & 0 & & \\
\hline$\overline{\mathbf{G}}$ & 13,4 & 33 & 4 & 3 & 0 & \\
\hline I & 11 & 5 & 43 & 92 & 4 & 0 \\
\hline Demand & 10 pcs & 10 pcs & 10 pcs & 10 pcs & 10 pcs & 10 pcs \\
\hline \multicolumn{7}{|c|}{ Pengiriman Tanggal 26 Februari 2020} \\
\hline Konsumen & $\mathbf{A}$ & D & $\mathbf{F}$ & $\mathbf{H}$ & K & \\
\hline A & 0 & & & & & \\
\hline D & 28,25 & 0 & & & & \\
\hline $\mathbf{F}$ & 26,5 & 26,7 & 0 & & & \\
\hline $\mathbf{H}$ & 10,8 & 11 & 10,8 & 0 & & \\
\hline $\mathbf{K}$ & 28,5 & 29,75 & 26,96 & 5,8 & 0 & \\
\hline Demand & 20 pcs & 10 pcs & 10 pcs & 10 pcs & 10 pcs & \\
\hline \multicolumn{7}{|c|}{ Pengiriman Tanggal 27 Februari 2020} \\
\hline Konsumen & A & B & C & $\bar{E}$ & $\mathbf{G}$ & $\mathbf{K}$ \\
\hline A & 0 & & & & & \\
\hline B & 13 & 0 & & & & \\
\hline C & 10 & 4 & 0 & & & \\
\hline $\mathbf{E}$ & 10 & 4 & 42,6 & 0 & & \\
\hline$\overline{\mathbf{G}}$ & 13,4 & 33 & 4 & 3 & 0 & \\
\hline $\mathbf{K}$ & 28,5 & 19 & 4,2 & 4 & 18,6 & 0 \\
\hline Demand & 10 pcs & 10 pcs & 10 pcs & 10 pcs & 10 pcs & 10 pcs \\
\hline \multicolumn{7}{|c|}{ Pengiriman Tanggal 28 Februari 2020} \\
\hline Konsumen & $\mathbf{A}$ & B & C & $E$ & $\mathbf{G}$ & $\mathbf{K}$ \\
\hline A & 0 & & & & & \\
\hline B & 13 & 0 & & & & \\
\hline C & 10 & 4 & 0 & & & \\
\hline E & 10 & 4 & 42,6 & 0 & & \\
\hline $\mathbf{G}$ & 13,4 & 33 & 4 & 3 & 0 & \\
\hline $\mathbf{K}$ & 28,5 & 19 & 4,2 & 4 & 18,6 & 0 \\
\hline Demand & 10 pcs & 10 pcs & 10 pcs & 10 pcs & 10 pcs & 10 pcs \\
\hline \multicolumn{7}{|c|}{ Pengiriman Tanggal 2 Maret 2020} \\
\hline Konsumen & $\mathbf{A}$ & B & C & D & $\mathbf{F}$ & $\mathbf{I}$ \\
\hline A & 0 & & & & & \\
\hline B & 13 & 0 & & & & \\
\hline $\mathbf{C}$ & 10 & 4 & 0 & & & \\
\hline D & 28,25 & 19 & 5 & 0 & & \\
\hline $\mathbf{F}$ & 26,5 & 18 & 2 & 26,7 & 0 & \\
\hline $\mathbf{J}$ & 11 & 5 & 35,8 & 11 & 11 & 0 \\
\hline Demand & 10 pcs & 10 pcs & 10 pcs & 10 pcs & 10 pcs & 10 pcs \\
\hline \multicolumn{7}{|c|}{ Pengiriman Tanggal 3 Maret 2020} \\
\hline Konsumen & $\mathbf{A}$ & B & C & D & $\mathbf{G}$ & $\mathbf{K}$ \\
\hline A & 0 & & & & & \\
\hline B & 13 & 0 & & & & \\
\hline C & 10 & 4 & 0 & & & \\
\hline D & 28,25 & 19 & 5 & 0 & & \\
\hline $\mathbf{G}$ & 13,4 & 33 & 4 & 13 & 0 & \\
\hline $\mathbf{K}$ & 28,5 & 19 & 4,2 & 29,75 & 18,6 & 0 \\
\hline Demand & 10 pcs & 10 pcs & 10 pcs & 10 pcs & 10 pcs & 10 pcs \\
\hline
\end{tabular}




\subsection{Mengalokasikan Konsumen}

Pada saat menandai konsumen ke kendaraan harus di usahakan agar dapat memaksimalkan penghematan, proses diawali dengan masingmasing konsumen diberi tanda untuk rute yang terpisah.[11] Dua rute bisa di kombinasikan menjadi satu rute jika pengiriman kedua rute tidak melebihi kapasitas alat angkut, pada masing-masing langkah bisa digunakan penggabungan rute pengiriman dengan mempertimbangkan penyimpanan tertinggi yang menjadi rute baru dengan menggunakan metode saving matrix [12]. Langkah penggabungan atau pengelompokan konsumen dimulai dari nilai penghematan terbesar, dan untuk angka yang di cetak tebal pada Tabel 4. adalah angka penghematan. Maka alokasi konsumen ke kendaraan atau rute berakhir dengan 7 rute untuk 7 hari, seperti yang ditampilkan pada Tabel $\underline{5}$.

Tabel 5. Alokasi Konsumen untuk 7 Hari

Alokasi konsumen untuk 7 hari

Pengiriman Tanggal 24 Februari 2020

Rute 1: Konsumen D, K, A, F dan C dengan total beban $=60$ Pcs

Pengiriman Tanggal 25 Februari 2020

Rute 1: Konsumen E, I, B, G, A dan C dengan total beban $=60$ Pcs

Pengiriman Tanggal 26 Februari 2020

Rute 1: Konsumen D, K, A, F dan $\mathrm{H}$ dengan total beban $=60$ Pcs

Pengiriman Tanggal 27 Februari 2020

Rute 1: Konsumen C, E, B, G, A dan K dengan total beban $=60$ Pcs

Pengiriman Tanggal 28 Februari 2020

Rute 1: Konsumen C, E, B, G, A dan K dengan total beban $=60$ Pcs

Pengiriman Tanggal 2 Maret 2020

Rute 1: Konsumen C, J, A, D, B dan F dengan total beban $=60$ Pcs.

Pengiriman Tanggal 3 Maret 2020

Rute 1: Konsumen B, G, D, K, A dan C dengan total beban $=60$ Pcs

\subsection{Metode Nearest neighbor}

Setelah alokasi konsumen ke kendaraan selama 7 hari, langkah selanjutnya adalah menentukan urutan kunjungan konsumen dengan metode nearest neighbor.[13] Proses diawali dari gudang kemudian dilanjutkan dengan mencari lokasi konsumen yang belum dikunjungi dengan jarak terpendek dari gudang, kemudian proses dilanjutkan ke lokasi lain dengan jarak terdekat dari lokasi yang telah terpilih sebelumnya dan tidak melebihi kapasitas kendaraan, seperti yang ditujukan pada Tabel.6.

Tabel 6. Pengalokasian menggunakan Metode Nearest neighbor

Pengalokasian menggunakan metode nearest neighbor

Pengiriman Tanggal 24 Februari 2020

$$
\text { G-A-K-D-F-C-G }
$$

Pengiriman Tanggal 25 Februari 2020

$$
\text { G-A-B-G-C-E-I-G }
$$

Pengiriman Tanggal 26 Februari 2020

$$
\text { G-A-K-D-F-H-G }
$$

Pengiriman Tanggal 27 Februari 2020

$$
\text { G-A-K-B-G-C-E-G }
$$

Pengiriman Tanggal 28 Februari 2020

$$
\text { G-A-K-B-G-C-E-G }
$$

Pengiriman Tanggal 2 Maret 2020

$$
\text { G-F-A-D-B-J-C-G }
$$

Pengiriman Tanggal 3 Maret 2020

$$
\text { G-A-K-D-B-G-C-G }
$$

Setelah dilakukan pengalokasian menggunakan metode nearest neighbor di dapatkan perbandingan jarak tempuh antara pengiriman awal existing perusahaan dan setelah menggunakan metode saving matrix dan nearest neighbor seperti yang ditujukan Tabel 7.

Tabel 7. Total Jarak Tempuh

\section{Total Jarak Tempuh}

\begin{tabular}{crr} 
Tanggal & Rute Awal & Rute Akhir \\
\hline 24 Februari 2020 & $166 \mathrm{Km}$ & $79,05 \mathrm{Km}$ \\
25 Februari 2020 & $360 \mathrm{Km}$ & $175,4 \mathrm{Km}$ \\
26 Februari 2020 & $171,6 \mathrm{Km}$ & $64,05 \mathrm{Km}$ \\
27 Februari 2020 & $278 \mathrm{Km}$ & $150,5 \mathrm{Km}$ \\
28 Februari 2020 & $278 \mathrm{Km}$ & $150,5 \mathrm{Km}$ \\
2 Maret 2020 & $212 \mathrm{Km}$ & $97,45 \mathrm{Km}$ \\
3 Maret 2020 & $208 \mathrm{Km}$ & $93,75 \mathrm{Km}$ \\
Total & $\mathbf{1 6 7 3 , 6 ~ K m}$ & $\mathbf{8 1 0 , 7 ~ K m}$ \\
Selisih & $\mathbf{8 6 2 , 9 ~ K m}$ \\
\hline
\end{tabular}


Pada Tabel 7. dijelaskan keseluruhan perbandingan jumlah rute dan jarak tempuh pengiriman sebelum dan setelah menggunakan metode saving matrix dan nearest neighbor, yang awalnya perusahaan memiliki paling banyak 6 rute setiap hari dalam sekali pengiriman atau 40 rute pada 7 hari di bulan Februari dan Maret 2020 sebelum diberlakukannya metode saving matrix semula total jarak tempuh 1.673,6 Km. Setelah diberlakukannya metode saving matrix, rute distribusi menjadi 7 rute untuk 7 hari dan total jarak pengiriman di perusahaan mengalami penurunan yang sangat signifikan yaitu menjadi 810,7 Km, dengan demikian didapatkan penghematan jarak sebesar 862,9 Km.

\subsection{Biaya Transportasi}

Biaya Transportasi merupakan biaya yang dikeluarkan oleh pihak perusahaan untuk kegiatan distribusi yaitu fixed cost dan variable cost[14]. Yang termasuk dalam fixed cost yaitu gaji pegawai yang ditambahkan pada akhir perhitungan serta biaya pemeliharaan dan pajak kendaraan dikarenakan perusahaan memiliki kendaraan sendiri, kemudian yang termasuk variable cost yaitu biaya bahan bakar (solar), jarak rute kendaraan, dan biaya retribusi[15].

Rumusan dalam penyelesaian biaya transportasi adalah:

Transportation cost

$$
\begin{aligned}
& =\text { Fixed cost }+ \text { Variable cost } \\
& =a+b \ldots \ldots \ldots \ldots \ldots \ldots \ldots \ldots \ldots \ldots \ldots \ldots
\end{aligned}
$$

Pada PT. MMM terdapat 1 pegawai pengiriman dan Gaji Pegawai mengikuti UMK Kota Karawang tahun 2020 yaitu Rp. 4.589.700/bulan, karena didalam penelitian hanya 7 hari maka gaji supir dihitung per harinya adalah Rp. 208.600. Kemudian biaya kendaraan per kilometer adalah Rp. 930 karena harga solar tahun 2020 adalah Rp. 9.300/liter, maka besarnya biaya yang dikeluarkan dalam satuan kilometer adalah $\mathrm{Rp}$. 930/Km dikarenakan satu liter solar diasumsikan habis dengan jarak $10 \mathrm{Km}$ dan jarak kunjungan yang digunakan adalah total jarak perhitungan setelah menggunakan nearest neighbor serta biaya retribusi yang diberikan perusahaan sebesar Rp. 50.000 untuk sekali pengiriman. Diketahui biaya tetap perusahaan diantaranya yaitu biaya pemeliharaan sebesar Rp. 10.000.000.- untuk 1 tahun atau 12 bulan, dari biaya 1 tahun itu diperkecil menjadi 1 bulan maka biaya pemeliharaan kendaraan sebesar Rp. 835.000/bulan dan biaya pajak kendaraan sebesar Rp. 3.321.500.- untuk 1 tahun, dari biaya 1 tahun itu kita perkecil juga menjadi 1 bulan maka biaya pajak kendaraan sebesar Rp. 276.800.- serta jumlah Fixed Cost yang telah diperoleh sebesar Rp. 1.460.200.-.

Contoh perhitungan Total Biaya Transportasi Rute awal dan usulan yaitu :

Awal

$=$ Rp. $930 / \mathrm{Km}$ X $166 \mathrm{Km}+$ Rp. 50.000

= Rp. 204.380.

Usulan

$=$ Rp. 930/Km X 79.05 Km + Rp. 50.000

$=$ Rp. 123.517.

Untuk keseluruhan hasil perhitungan Total Biaya Transportasi terdapat dalam Tabel 8.

Tabel 8. Total Biaya Transportasi

\begin{tabular}{cccc}
\hline No & $\begin{array}{c}\text { Biaya } \\
\text { Transportasi } \\
\text { Rute Awal }\end{array}$ & $\begin{array}{c}\text { Biaya } \\
\text { Transportasi } \\
\text { Rute Usulan }\end{array}$ & Selisih \\
\hline 1 & 204.380 & 123.517 & 80.864 \\
2 & 384.800 & 213.122 & 171.678 \\
3 & 209.588 & 109.567 & 100.022 \\
4 & 308.540 & 189.965 & 118.575 \\
5 & 308.540 & 189.965 & 118.575 \\
6 & 247.160 & 140.629 & 106.532 \\
7 & 243.440 & 137.188 & 106.253 \\
Biaya & 2.572 .000 & 2.572 .000 & \\
Tetap & & & \\
Total & $\mathbf{R p . 4 . 4 7 8 . 4 4 8}$ & $\mathbf{R p . 3 . 6 7 5 . 9 5 1}$ & $\mathbf{R p . 8 0 2 . 4 9 7}$ \\
Biaya & & & \\
\hline
\end{tabular}

\section{KESIMPULAN}

Dari hasil keseluruhan pengolahan data diatas diperoleh kesimpulan dimana rute awal distribusi sebanyak 40 rute, kemudian dengan perhitungan metode saving matrix dan metode nearest neighbor menghasilkan rute baru yang efektif dan efisien menjadi 7 rute untuk 7 hari pendistribusian dengan mempertimbangkan kapasitas alat angkut produk ke konsumen, dan diterapkannya metode saving matrix menunjukan penurunan jarak tempuh pengiriman yang semula 1.673,6 $\mathrm{Km}$ menjadi $810,7 \mathrm{Km}$ dengan demikian penghematan jarak sebesar 862,9 Km, serta menurunkan biaya transportasi dimana biaya awal transportasi sebesar Rp. 4.478.448.turun menjadi Rp. 3.675.951.- sehingga perusahaan dapat menghemat biaya transportasi sebesar Rp. 802.497.-. Diharapkan penelitian selanjutnya mampu secara langsung menghitung dengan metode yang sama dan menggunakan software pendukung sehingga pendistribusian dilakukan dengan efisien. 


\section{DAFTAR PUSTAKA}

[1] E. Adriantantri, J. D. Irawan, and S. Indriani, "Implementasi Metode Saving Matriks Pada Program Komputer Untuk Penentuan Pendistribusian Produk," Ind. Inov. J. Tek. Ind., vol. 5, no. 1, pp. 10-14, 2015. Available:

https://ejournal.itn.ac.id/index.php/industri/ar ticle/view/1112.

[2] S. Supriyadi, K. Mawardi, and A. Nalhadi, "Minimasi Biaya Dalam Penentuan Rute Distribusi Produk Minuman Menggunakan Metode Savings Matrix," in Seminar Nasional Institut Supply Chain dan Logistik Indonesia (ISLI), 2017, pp. 1-7. Available: https://ejurnal.Ippmunsera.org/index.php/se nasset/article/view/475.

[3] Y. P. Muhajir, "Penentuan Rute Distribusi Optimal Menggunakan Metode Saving Matrix pada PT. XYZ," Skripsi. Universitas Sumatera Utara, 2018. Available: http://repositori.usu.ac.id/handle/123456789 17989.

[4] B. Muhammad and M. Rahmi, "Penentuan Rute Transportasi Distribusi Sirup Untuk Meminimalkan Biaya," Malikussaleh Ind. Eng. J., vol. 6, no. 1, pp. 10-15, 2017. Available:

https://journal.unimal.ac.id/miej/article/view/ 152.

[5] M. M. Huda, "Penentuan rute distribusi menggunakan metode saving matrix untuk meminimalkan biaya transportasi di pt. Lima jaya abadi," Skripsi. Universitas 17 AGUSTUS 1945, 2018. Available: http://repository.untag-sby.ac.id/650/.

[6] H. Sudjono and S. Noor, "Penerapan Supply Chain Management Pada Proses Manajemen Distribusi Dan Transportasi Untuk Meminimasi Waktu Dan Biaya Pengiriman," J. Poros Tek., vol. 3, no. 1, pp. 26-33, Available: https://ejurnal.poliban.ac.id/index.php/porost eknik/article/view/40.

[7] I. K. Sriwana, . A., and A. F. Rewa, "Usulan Perbaikan Rute Pendistribusian Produk dengan Menggunakan Analisis Bullwhip Effect, Metode Nearest Insert Dan Nearest Neighbor (Studi Kasus di PT. YNP)," J. IIm. Tek. Ind., vol. 4, no. 3, pp. 140-155, Mar.
2018, doi: 10.24912/jitiuntar.v4i3.1543.

[8] R. Rahmawati, "Usulan Model dalam Menentukan Rute Distribusi untuk Meminimalkan Biaya Transportasi dengan Metode Saving Matrix di PT. Xyz," J. Tek. Ind. USU, vol. 5, no. 2, pp. 5-10, 2014. Available:

https://jurnal.usu.ac.id/index.php/jti/article/vi ew/12391.

[9] R. Yuniarti and M. Astuti, "Penerapan metode saving matrix dalam penjadwalan dan penentuan rute distribusi premium di SPBU Kota Malang," Rekayasa Mesin, vol. 4, no. 1, pp. 17-26, 2013. Available: https://rekayasamesin.ub.ac.id/index.php/rm /article/view/173.

[10] A. Momon and D. W. Ardiatma, "Penentuan Rute Distribusi Suku Cadang Kendaraan Bermotor dalam Meminimalkan Biaya Transportasi (Studi Kasus: PT. Inti Polymetal Karawang)," JIEMS (Journal Ind. Eng. Manag. Syst., vol. 11, no. 1, pp. 1724, Mar. 2018, doi: 10.30813/jiems.v11i1.1012.

[11] T. Y. T. Kusuma, "Analisis Material Requirement Planning (MRP) di C-Maxi Alloycast," Integr. Lab J. vol. 5, no. 2, pp. 81-94, 2017, Available: http://202.0.92.5/pusat/integratedlab/article/ view/1556.

[12] Y. Siyamtining Tyas and W. Prijodiprodjo, "Aplikasi Pencarian Rute Terbaik dengan Metode Ant Colony Optimazation (ACO)," IJCCS (Indonesian J. Comput. Cybern. Syst., vol. 7, no. 1, pp. 55-64, Jan. 2013, doi: $10.22146 /$ ijccs.3052.

[13] U. N. Azizah and T. I. Oesman, "Optimalisasi Biaya Distribusi Produk PT. Madubaru dengan Pendekatan Metode Saving Matrix Dan Generalized Assignment," J. Rekavasi, vol. 3, no. 2, pp. 102-110, $2015 . \quad$ Available: https://ejournal.akprind.ac.id/index.php/reka vasi/article/view/312.

[14] A. Arifudin, P. Wisnubroto, and C. I. Parwati, "Optimalisasi Vehicle Routing Problem Dengan Pendekatan Metode Saving Matrix dan Clarke \& Wright Saving Heuristic," J. Rekavasi, vol. 5, no. 1, pp. 1-9, 2017. Available: https://ejournal.akprind 
[15] A. G. Makalew, A. H. Jan, and M. M. Karuntu, "Analisis Peran Supply Chain Management Terhadap Keunggulan Bersaing Pada PT. Mitra Kencana Distribusindo Manado," J. EMBA J. Ris. Ekon. Manajemen, Bisnis dan Akunt., vol. 7, no. 4, pp. 5446-5455, 2019. Available: https://ejournal.unsrat.ac.id/index.php/emba/ article/view/26323.

\section{Biografi Penulis}

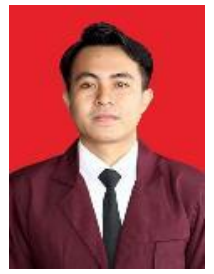

\section{Fery Darus Nasution}

Saat ini tercatat sebagai mahasiswa Teknik Industri Universitas Singaperbangsa Karawang.

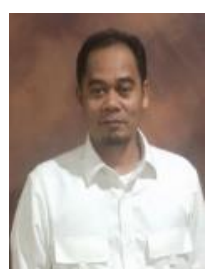

\section{Ade Momon S.}

Saat ini tercatat sebagai dosen Program Studi Teknik Industri Universitas Singaperbangsa Karawang.

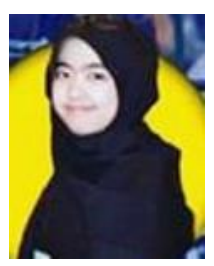

\section{Risma Fitriani}

Saat ini tercatat sebagai dosen Program Studi Teknik Industri Universitas Singaperbangsa Karawang.

\section{Lampiran}

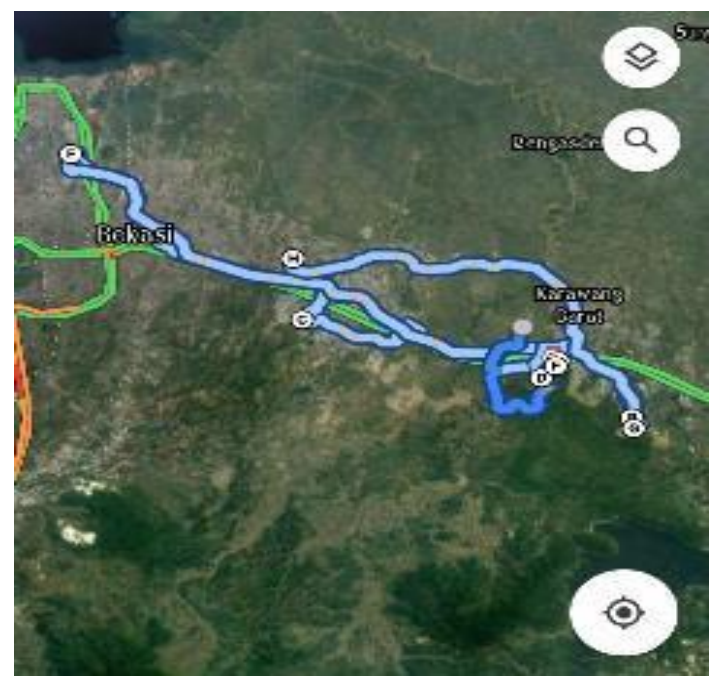

Gambar 2. Dokumentasi Rute Pengiriman Awal
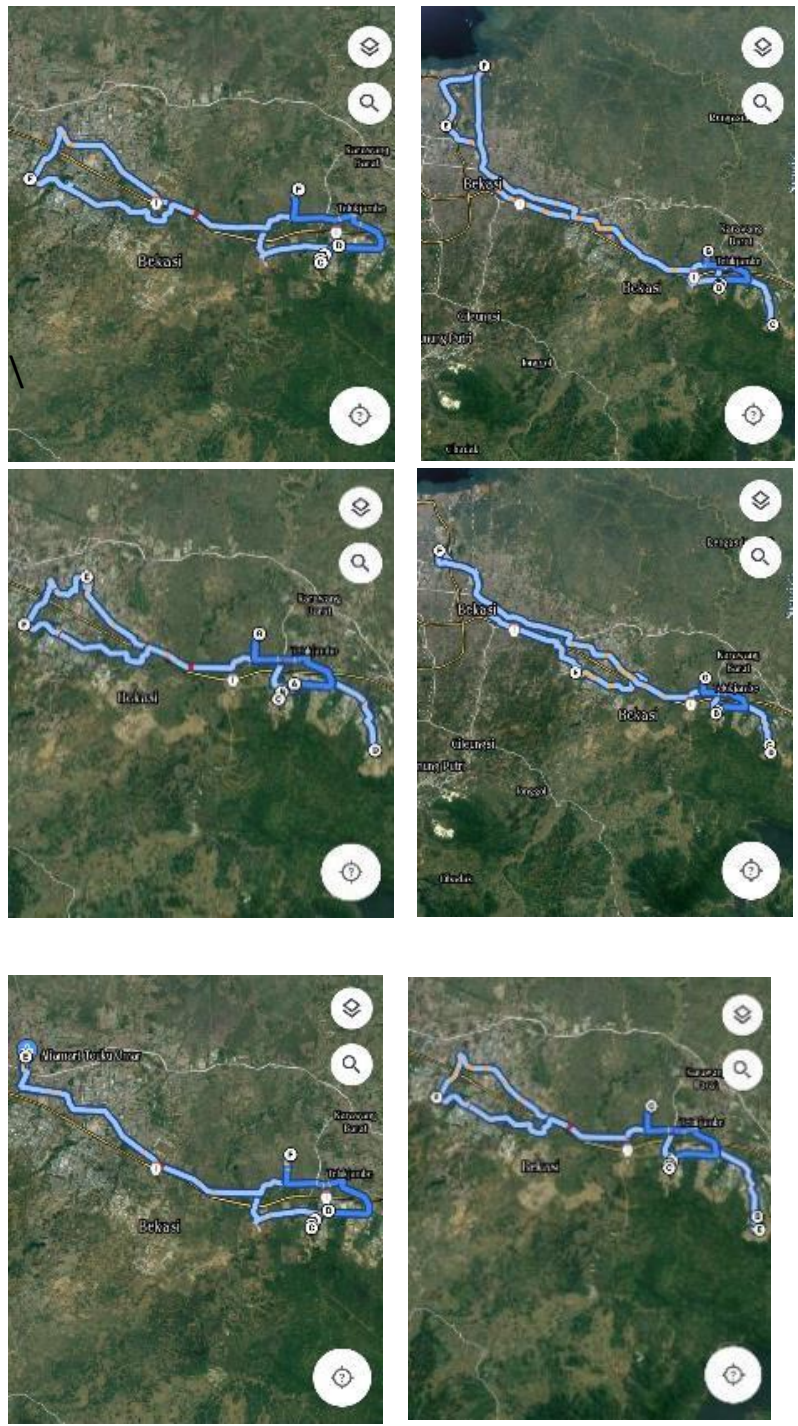

Gambar 3. Dokumentasi Rute Pengiriman Usulan 